\title{
ANTIOXIDANT ACTIVITY OF AQUEOUS EXTRACTS FROM DILL FRUIT (Anethi fructus) OBTAINED BY DIFFERENT EXTRACTION TECHNIQUES
}

Ljiljana P. Stanojević ${ }^{1 *}$, Mihajlo Z. Stanković ${ }^{1}$, Amer Juma ${ }^{2}$

\footnotetext{
${ }^{1}$ Faculty of Technology, Leskovac, University of Niš, Leskovac, Serbia
}

2Al. Rafideen doo, Leskovac, Serbia
(ORIGINAL SCIENTIFIC PAPER)

UDC 582.794.1:66.061
The antioxidant activity of aqueous extracts from dill fruit (Anethum graveolens L.) using DPPH, FRAP and FIC methods was investigated in this work. Aqueous extracts from dill fruit were obtained using different extraction techniques (maceration, reflux extraction, ultrasonic extraction, Soxhlet and Tillepape extraction). The aqueous extract obtained by Soxhlet extraction showed the highest antioxidant activity, independently of the applied antioxidant methods. There was a positive linear correlation between total phenolics and flavonoids content with the antioxidant activity. The presented results indicate that the bioactive substances, phenols and flavonoids, are probably mainly responsible for the antioxidant activity of the analyzed extracts. Also, the presented results suggest that aqueous extracts from dill fruit are a potential source of natural antioxidants as an alternative to synthetic additives.
Keywords: Anethum graveolens L.; Dill fruit; extraction techniques; antioxidant activity; total phenolics and flavonoids.

\section{Introduction}

There is the increasing number of scientific investigations with the aim of finding natural products that posses different biological activities such as antioxidant, antimicrobial and anti-inflammatory activities. This activities are most commonly studied [1].

The important trend in food industry is a discovery of natural antioxidants from the plant material [2]. The most important synthetic antioxidants which are added to oils and foods are ascorbyl palmitate (AP), tert-butyl-4-hydroxyanisole (BHA), tert-butyl-4-hydroxytoluene (BHT), propyl gallate $(P G)$, butyl gallate $(B G)$, octyl gallate $(O G)$, dodecyl gallate (DG). But, synthetic antioxidants also have some undesirable side effects [3].

Anethum graveolens L., commonly known as dill, is an aromatic annual or biennial medicinal plant from the genus Anethum of the family Apiaceae (Umbelliferae) [4]. It is condiment crop with a specific aroma and odor, and it is one of the most significant spices in food industry $[4,5,6]$. Herb and fruits of dill have been used in food industry for sauces, salads and seafood [7,8]. Dill is well known as a medicinal herb with antioxidative, antimicrobial, hypotensive, antihyperlipidemic, diuretic, antiemetic, laxative and spasmolytic effects $[9,10,11,12]$. The dill fruit contains polyphenolic compounds, among which flavonoids (quercetin and rutin), derivatives of hydroxycinnamic acid (chlorogenic acid) and coumarins (scopoletin) are the most important [13]. Dill is traditionally used to relieve fatigue in sleep disorders, as well as in the prevention and treatment of various diseases: dysfunction of gastrointestinal tract, kidney and urinary tract diseases, insomnia and spasms [9].

There is no comparative study of the antioxidant activity of aqueous extracts from dill fruit obtained by different extraction techniques. Because dill fruit is one of the most commonly used spices in Serbian traditional cuisine and food industry and, at the same time, dill is a plant with many medicinal properties. The aim of this work was to investigate the antioxidant activity of aqueous extracts from dill fruits obtained by five different extraction techniques, by three antioxidant assay: DPPH, FRAP and FIC test. In addition, the correlation of the antioxidant activity with total phenolics and flavonoids was determined. The potentials of aqueous extracts from dill fruit for practical use have not been previously studied in detail, so this work has obtained potentially important results concerning natural antioxidants in the fruit of the dill.

\section{Experimental}

\section{Plant material}

The dill fruit (Anethi fructus) has been used in this investigation. The plant material was obtained from the Institute for Medicinal Plant Research "Dr Josif Pančić", Belgrade during the year 2013. The dry plant material was ground in the laboratory mil (BRAUN AROMATIC KSM2) immediately before analysis.

\footnotetext{
*Author address: Ljiljana Stanojević, Faculty of Technology, Leskovac, University of Niš, Bulevar oslobidjenja 124, 16000 Leskovac, Serbia,

E-mail: ljiljas76@yahoo.com; stanojevic@tf.ni.ac.rs

The manuscript received: November, 04, 2016.

Paper accepted: November, 30, 2016.
} 
Reagents and chemicals

2,4,6-Tris(2-pyridyl)-1,3,5-triazine (TPTZ reagent), 1,1-diphenyl-2-picrylhydrazyl (DPPH) radical, sodium acetate trihydrate, iron (III) chloride hexahydrate, iron (II) sulphate heptahydrate, butylated hydroxy-toluene $(\mathrm{BHT})$, etilendiamin-tetra-acetic acid (EDTA) (Sigma Chemical Company, St. Louis, USA). All other chemicals were analytical-grade (p.a.).

\section{Extraction techniques}

Maceration

The plant material $(1.5 \mathrm{~g})$ was extracted by maceration with water $\left(30 \mathrm{~cm}^{3}\right)$. Maceration was performed for 180 minutes with hydromodule (plant material/water ratio) $1: 20 \mathrm{~m} / \mathrm{v}$ at $25^{\circ} \mathrm{C}$. The extract was separated by filtering under a weak vacuum at $40^{\circ} \mathrm{C}$. The obtained extract was evaporated under vacuum at $40{ }^{\circ} \mathrm{C}$ to constant weight, and the content of extractive matter (dry extract) was calculated on the basis of dry residue content [5].

\section{Reflux extraction}

The plant material $(1.5 \mathrm{~g})$ was extracted by reflux extraction with water (hydromodule, 1:20 m/v) at boiling temperature. The extraction was performed for 180 minutes. The dry extract was obtained using the same procedure as described in the section Maceration [5].

\section{Soxhlet and Tillepape extraction}

The plant material $(10 \mathrm{~g})$ and water $\left(200 \mathrm{~cm}^{3}\right)$ were put into the Soxhlet and Tillepape apparatus and extractions were performed for 240 minutes. After 240 minutes, liquid extracts were evaporated under vacuum at $40{ }^{\circ} \mathrm{C}$ to constant weight by the same procedure as desribed in the section Maceration. The obtained dry extracts were stored at $+4{ }^{\circ} \mathrm{C}$ for subsequent analysis [5].

\section{Ultrasonic extraction}

The plant material $(1.5 \mathrm{~g})$ was extracted with water (hydromodule, $1: 20 \mathrm{~m} / \mathrm{v}$ ) in the presence of low-frequency ultrasound. The extraction was performed for $30 \mathrm{~min}-$ utes using an ultrasonic bath (Sonic, Niš, Serbia; internal dimensions: $30 \times 15 \times 20 \mathrm{~cm}$; total nominal power: $3 \times 50 \mathrm{~W}$; and frequency: $40 \mathrm{kHz}$ ) at $25{ }^{\circ} \mathrm{C}$. The dry extract was obtained using the same procedure as described in the section Maceration [5].

\section{Antioxidant assays}

DPPH-test

DPPH test most commonly used in vitro method for the effective determination of antioxidant activities, based on hydrogen atoms or electrons exchange among antioxidants and DPPH radicals in the solution [14]. The ethanolic solution of DPPH radical $\left(1 \mathrm{~cm}^{3}, 3 \times 10^{-4} \mathrm{~mol} / \mathrm{dm}^{3}\right)$ was added in $2.5 \mathrm{~cm}^{3}$ of the extract (concentrations from 0.0156 to $1.0 \mathrm{mg} / \mathrm{cm}^{3}$ ). The absorbance at $517 \mathrm{~nm}$ was immediately measured in the first probe, while the absorbance in the second probe was measured after 20 min of incubation at room temperature in the dark (Au). The absorbance was also measured in the pure ethanolic solution of DPPH radical, diluted in an adequate proportion (1 $\mathrm{cm}^{3}$ of DPPH radical, $3 \times 10-4 \mathrm{~mol} / \mathrm{cm}^{3}$, diluted with $2.5 \mathrm{~cm}^{3}$ of ethanol - "control", $A_{c}$ ), and in the extract without DPPH radical adding $\left(2.5 \mathrm{~cm}^{3}\right.$ of extract diluted with $1 \mathrm{~cm}^{3}$ of ethanol - "blank", $A_{b}$ ). Free radical scavenging capacity is calculated according to Eq. 1 [15].

DPPH radicals neutralization $(\%)=100-\left[\left(A_{U}-A_{B}\right) \times \frac{100}{A_{C}}\right] \ldots \ldots \ldots . . . . .$.

The extract concentration needed for the neutralization of $50 \%$ of the initial DPPH radical concentration is called $\mathrm{EC}_{50}$ value. This value was determined by using a linear regression analysis in the concentration range between 0.0156 and $0.7 \mathrm{mg} / \mathrm{cm}^{3}$ of the extract added to the reaction mixture.

DPPH test of synthetic antioxidant BHT was also performed. $\mathrm{EC}_{50}$ value of synthetic antioxidants, BHT was under the same experimental conditions, $0.021 \mathrm{mg} / \mathrm{cm}^{3}$ [17].

\section{FRAP test}

The antioxidant activity of dill fruit aqueous extracts was determined by FRAP test according to the method of Benzie and Strain [16] with some modifications [5, 17]. FRAP reagent was prepared from acetate buffer (300 $\left.\mathrm{mmol} / \mathrm{dm}^{3}, \mathrm{pH}=3.6\right)$, TPTZ reagent $\left(10 \mathrm{mmol} / \mathrm{dm}^{3}\right.$ in $\left.40 \mathrm{mmol} / \mathrm{dm}^{3} \mathrm{HCl}\right)$ and $\mathrm{FeCl}_{3} \times 6 \mathrm{H}_{2} \mathrm{O}\left(20 \mathrm{mmol} / \mathrm{dm}^{3}\right)$ in 10:1:1 ratio. The calibration curve was constructed according to absorbance values, measured at $593 \mathrm{~nm}$, for $\mathrm{FeSO}_{4} \times 7 \mathrm{H}_{2} \mathrm{O}$

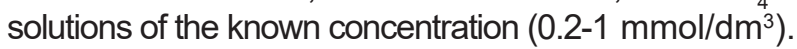

The extract $\left(0.1 \mathrm{~cm}^{3}\right)$ and FRAP reagent $\left(3 \mathrm{~cm}^{3}\right)$ were mixed in the test tube and after 30 minutes of incubation at $37{ }^{\circ} \mathrm{C}$ in the water bath, the absorbance at $593 \mathrm{~nm}$ was measured against blank. The concentration of $\mathrm{Fe}^{2+}$ $\left(\mathrm{mmol} / \mathrm{dm}^{3}\right)$ in the sample was determined from the calibration curve equation. FRAP value was calculated based on the dry extract weight $\left(\mathrm{mmol} \mathrm{Fe} \mathrm{Fe}^{2+} / \mathrm{g}\right.$ d.e.) and it is called the FRAP value $[15,17]$.

\section{FIC test}

FIC (Ferrous ion-chelating) activity can be used as a test of the antioxidant activity and it is a measure of absorbance decreasing (at $562 \mathrm{~nm}$ ) of iron (II) - Ferrozine complex. Chelating ability was determined according to the method described by Dinis and co-workers [18] with some modifications [17]. Ethanol $\left(3.75 \mathrm{~cm}^{3}\right)$ and $0.05 \mathrm{~cm}^{3}$ of $2 \mathrm{mM} \mathrm{FeCl} \times 4 \mathrm{H}_{2} \mathrm{O}$ was added in the solution of different extract concentrations ( $1 \mathrm{~cm}^{3}, 0.031-2.5 \mathrm{mg} / \mathrm{cm}^{3}$ - "sample"). The reaction was initiated by adding $0.2 \mathrm{~cm}^{3}$ of $5 \mathrm{mM}$ Ferrozine solution, after which the mixture was incubated for $10 \mathrm{~min}$ at room temperature and the absorbance at $562 \mathrm{~nm}$ was measured. The absorbance was also measured for mixtures without test-samples (ethanol, Ferrozine and $\mathrm{FeCl}_{2} \times 4 \mathrm{H}_{2} \mathrm{O}$ - "control"), as well as for the extract before the treatment with $\mathrm{FeCl}_{2} \times 4 \mathrm{H}_{2} \mathrm{O}$ and Ferrozine $\left(1 \mathrm{~cm}^{3}\right.$ of the extract diluted with $4 \mathrm{~cm}^{3}$ of ethanol - "blank"). The solution of EDTA was used as a reference standard. A lower absorbance value indicates better FIC activity of 
test-samples. FIC activity (\%) was calculated by Eq. 2 [17].

Ferrous ion - chelating ability $(\%)=100-\left[\left(A_{U}-A_{B}\right) \times \frac{100}{A_{C}}\right]$

where: $A_{u}$ is absorbance of the "sample", $A_{B}$ is absorbance of the "blank" and $A_{C}$ is absorbance of the "control".

\section{Results and discussion}

The aqueous dill fruit extracts obtained by five extraction techniques were subjected to screening for their possible antioxidant activity. Three test systems, namely DPPH, FRAP and FIC test, were used for this purpose.

In our previous investigation of drill fruit we found that the content of total phenols and flavonoids, in aqueous extracts of dill fruit obtained by different techniques of extraction, depends on the extraction techniques used [5]. The total phenols and flavonoids content is higher in extracts obtained by circulation techniques of extraction (Soxhlet and Tillepape), as well as in the extract obtained by reflux extraction compared to the extracts obtained by maceration and ultrasonic extraction. The highest total phenolics (573.81 mg GAE/g d.e.) and flavonoids (12.96 mg RE/g d.e.) content was in the extract obtained by Soxhlet extraction [5]. This is probably due to a cir- cular flow of the solvent to the complete depletion of the plant material. The minimum content of total phenolics (539.01 mg GAE/g d.e.) and flavonoids (9.95 mg RE/g d.e.) [5] was determined in the extract obtained by the ultrasonic extraction. The content of phenolics and flavonoids obtained by ultrasonic extraction was lower by $6.06 \%$ and $23.22 \%$, respectively compared to the content obtained by Soxhlet extraction. This phenomenon can be explained by oxidation and degradation of some phenolic compounds due to the sonication of aqueous solutions, with the result as a consequence of the formation of reactive hydroxyl radicals under the influence of ultrasound $[19,20]$. According to our earlier investigations of nettle leaves extracts, it was found that the antioxidant activity of the extracts depend on the extraction technique used $[15,20]$.

In the reaction of DPPH test it comes to the reduction of intensely purple-colored DPPH radical to corresponding hydrazine, which was spectrophotometrically followed by the absorbance decreasing at $517 \mathrm{~nm}$ [14]. Figure $1(a-e)$ shows the percentage of DPPH radical neutralization with increasing the extracts concentration without and with incubation (20 min), while Table 1 presents the $\mathrm{EC}_{50}$ values for all extracts.
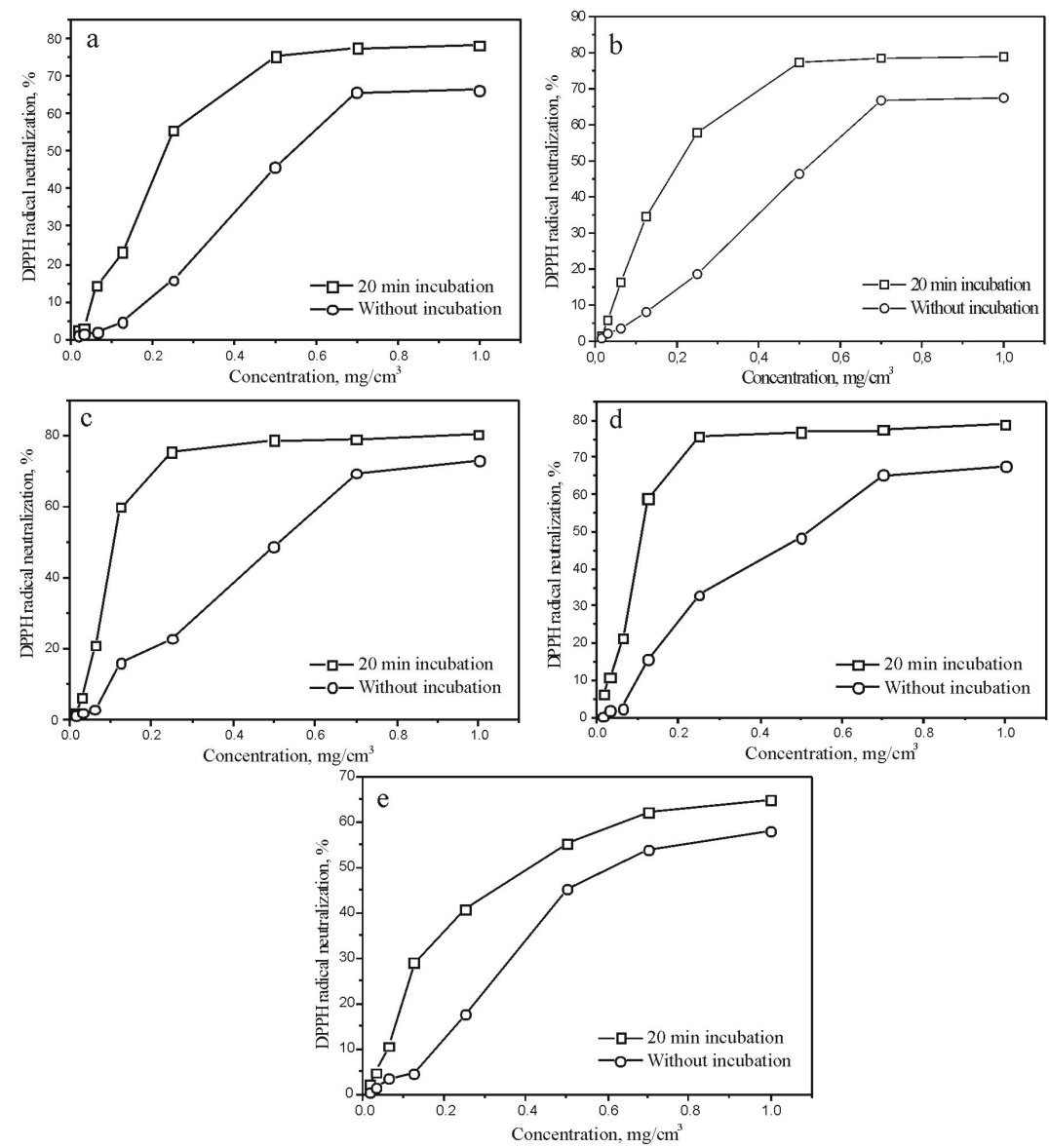

Figure 1. The capacity of DPPH radicals neutralization by aqueous extracts from the dill fruit obtained by maceration (a), reflux extraction (b), Soxlet (c), Tillepape (d) and ultrasonic extraction (e). 
Table 1. $E_{50}$ values of aqueous extracts from dill fruit obtained by different extraction techniques (obtained by DPPH test)

\begin{tabular}{ccc}
\hline \multirow{2}{*}{ Extraction technique } & \multicolumn{2}{c}{$\mathrm{EC}_{50}, \mathrm{mg} / \mathrm{cm}^{3}$} \\
incubation & $\begin{array}{c}\text { Without } \\
\text { incubation }\end{array}$ \\
\hline Maceration & 0.224 & 0.555 \\
Reflux extraction & 0.211 & 0.536 \\
Ultrasonic extraction & 0.417 & 0.623 \\
Soxhlet extraction & 0.111 & 0.513 \\
Tillepape extraction & 0.113 & 0.524 \\
\hline
\end{tabular}

EC50 - Concentration of the extract (in $\mathrm{mg}$ of the dry extract per $\mathrm{cm} 3$ of the extract) required for neutralizing $50 \%$ of the initial concentration of $\mathrm{DPPH}$ radicals

The results show that the incubation time had influence on the DPPH radical neutralization for all extract concentration. The degree of DPPH radical neutralization by the extracts obtained by different extraction techniques declines in a row: Soxhlet $>$ Tillepape $>$ reflux extraction $>$ maceration $>$ ultrasonic extraction. The extracts obtained by Soxhlet and Tillepape extractions show better DPPH radical neutralization than other extracts, which is probably a result of the highest contents of total phenolics and flavonoids in these extracts [5].

The lowest degree of DPPH radical neutralization was achieved by the extract obtained by ultrasonic extraction. Probably, this could be explaned by degradation of bioactive components, responsible for the antioxidant activity, under sonication [19]. The $\mathrm{EC}_{50}$-value is a parameter widely used to measure the free radical scavenging activity. The extract obtained by the Soxhlet extraction had the lowest $\mathrm{EC}_{50}$ value, meaning that it showed the best antioxidant activity. The antioxidant effect of all obtained extracts does not come from phenolic compounds only, but it is likely due to the synergistic effects of these compounds with other biomolecules isolated from the plant material. The information about these trials of the antioxidant activity is not found in the available literature [20].

As it can been seen from Figure 2, a positive linear correlation between the scavenging capacity of the extracts against DPPH radicals (expressed in $\mathrm{EC}_{50}$, for incubated extracts) and total phenolic $\left(R^{2}=0.728\right)$ and flavonoids $\left(R^{2}=0.914\right)$ content was established. Total flavonoids show better correlation with $\mathrm{EC}_{50}$ values, indicating that they are probably more responsible for the antioxidant activity of the extracts. Christopher-Bagdassarian and co-workers have confirmed the presence of phenols and flavonoids in methanol extracts of dill which are probably the most responsible for their antioxidant effect [21].

FRAP method is based on the reduction of [ $\left.\mathrm{Fe}^{3+}-\mathrm{TPTZ}\right]$ complex to the intense blue (absorption maximum $593 \mathrm{~nm}$ ) [Fe ${ }^{2+}$-TPTZ] complexes in acid medium. Reducing capacity is expressed by the mass of a standard reducing agent $\left(\mathrm{Fe}^{2+}\right.$, ascorbic acid and the like) which would cause the same level of the reduction of $\mathrm{Fe}^{3+}$-TPTZ [16]. The FRAP values of dill friuit aqueous extracts obtained by different extraction techniques for all extracts is presented in Table 2.
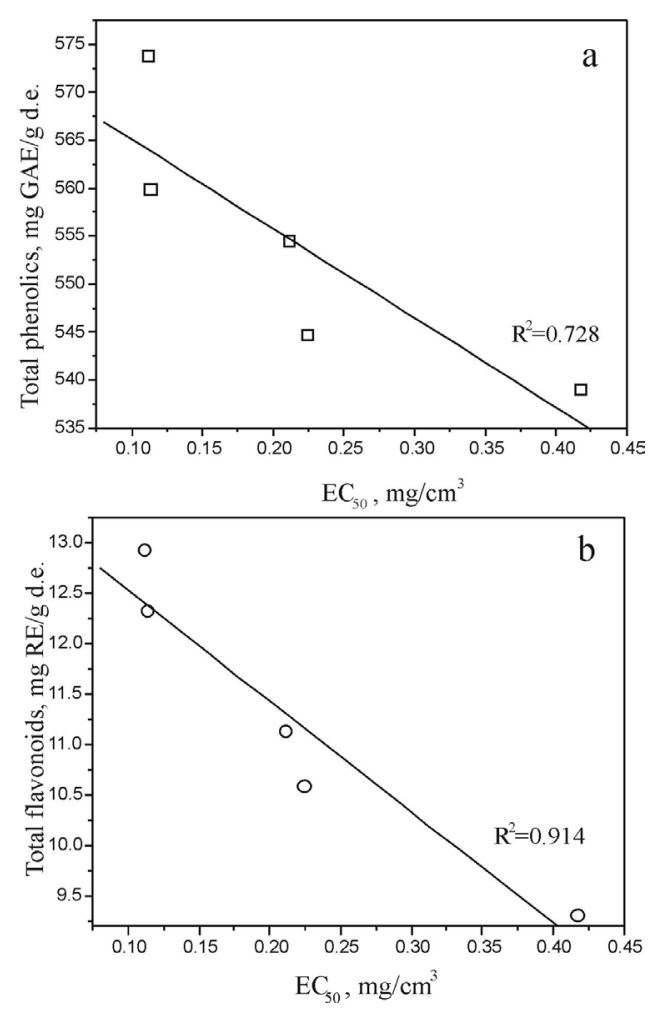

Figure 2. Linear correlation between total phenolics (a) and flavonoids (b) and $\mathrm{EC}_{50}$ values of aqueous extracts from the dill fruit obtained by different extraction techniques.

Table 2. FRAP values of aqueous extracts from dill fruit obtained by different extraction techniques

\begin{tabular}{cc}
\hline Extraction technique & FRAP, $\mathrm{mmol} \mathrm{Fe}^{2+} / \mathrm{g}$ d.e. \\
\hline Maceration & 0.513 \\
Reflux extraction & 0.540 \\
Ultrasonic extraction & 0.507 \\
Soxhlet extraction & 0.598 \\
Tillepape extraction & 0.580 \\
d.e. - dry extract
\end{tabular}

It can be seen that the highest FRAP value, and thus the best reductive capacity is shown by the extract obtained by Soxhlet extraction, which can be explained by the highest content of phenolic compounds in this extract. The good linear correlation between FRAP values and the content of total phenolic $\left(R^{2}=0.934\right)$ and flavonoids $\left(R^{2}=0.982\right)$ can be seen in Figure 3, which confirms that this bioactive components are probably responsible for the antioxidant activity of the dill fruit extracts.

Ferrous ion chelating (FIC) ability of the dill fruit aqueous extracts obtained by different extraction techniques is presented in Figure 4. Chelating effect of EDTA $\left(96.34 \%\right.$ in the concentration $\left.0.25 \mathrm{mg} / \mathrm{cm}^{3}\right)$ was reported in our earlier research [17]. 

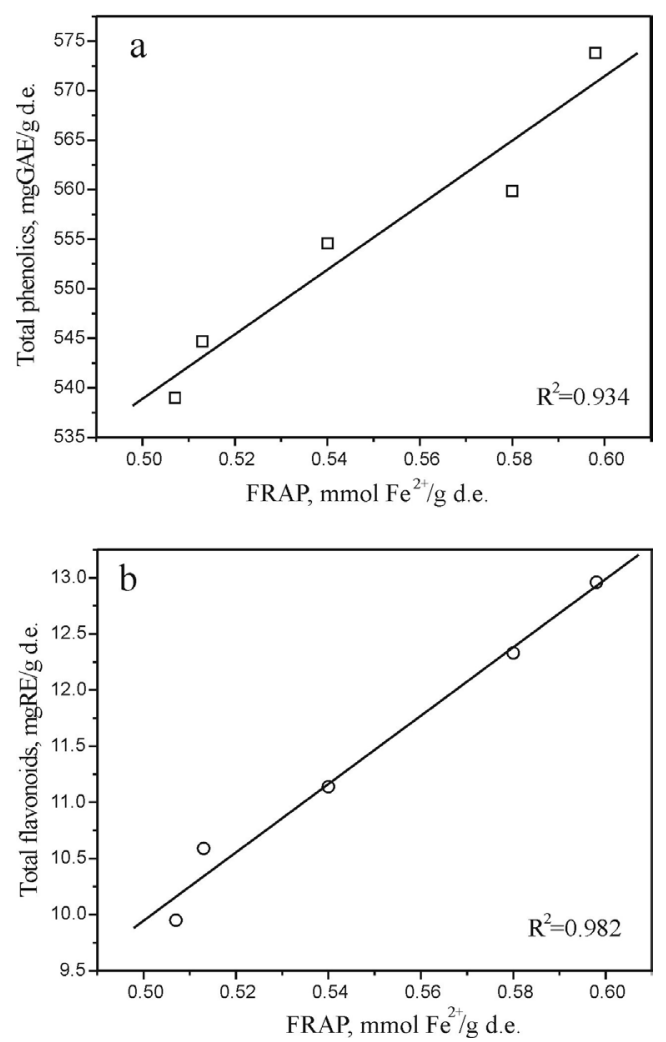

Figure 3. The correlation between FRAP values and total phenolics (a) and flavonoids (b) in the dill fruit aqueous extracts.

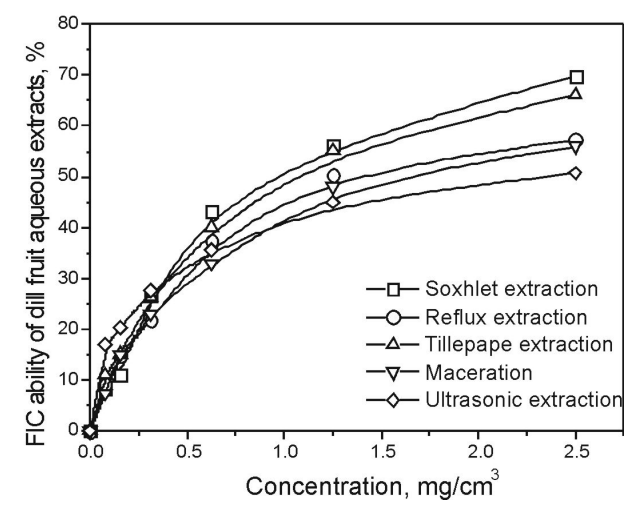

Figure 4. The FIC ability of dill fruit aqueous extracts.

The extract obtained by Soxhlet extraction contained a higher amount of phenolics and flavonoids, which is probably the reason of its higher chelating ability. According to some earlier investigations, there is a positive correlation between FIC activity and total phenolics content [22].

The FIC ability of the extracts (obtained by different extraction techniques, the concentration of $2.0 \mathrm{mg} / \mathrm{cm}^{3}$ ), in the function of total phenolics and flavonoids content, is represented in Figure 5.

It can be seen that there is a linear correlation of total phenolics $\left(R^{2}=0.918\right)$ and flavonoids $\left(R^{2}=0.990\right)$ content with FIC ability. The antioxidant activity determined by this test is also observed in previous investigations probably due to a high content of phenolic compounds. Many investigations also reported a high linear correlation between the antioxidant activity of different plant extracts and the content of total phenolics and favonoids in the extracts $[20,23]$.
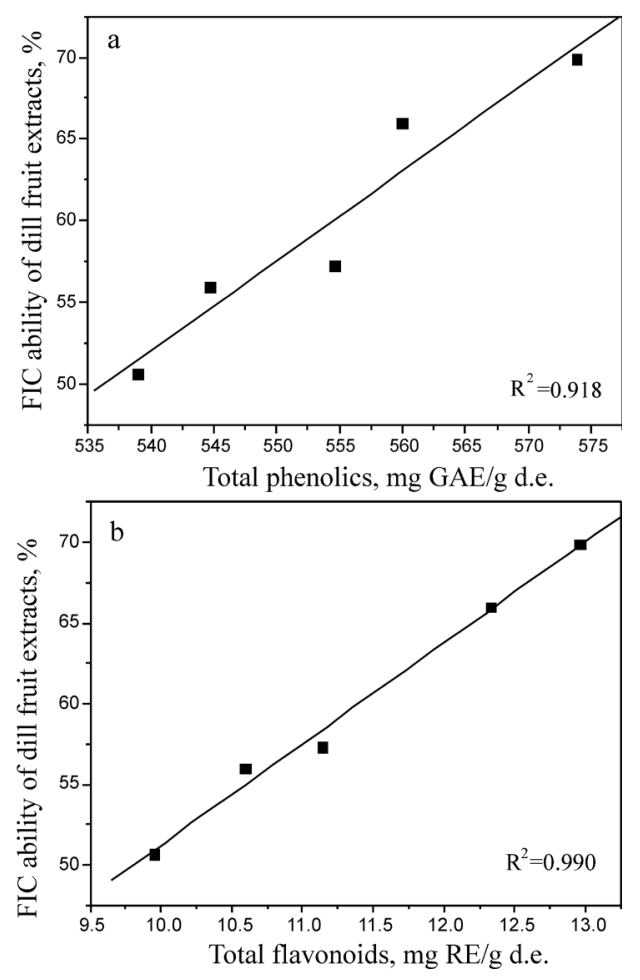

Figure 5. The correlation between FIC ability of the dill fruit extracts and total phenolics (a) and flavonoids (b) in the dill fruit extracts.

\section{Conclusion}

A comparative study of the antioxidant activity of aqueous extracts from the dill fruit obtained by five extraction techniques (maceration, reflux extraction, Soxhlet, Tillepape and ultrasonic extraction) was investigated. The antioxidant activity of the extracts depends on the extraction technique. The antioxidant activity of aqueous extracts from dill fruit, independently of the method applied (DPPH, FRAP and FIC test), decreases in line: Soxhlet>Tillepape>reflux extraction>maceration>ultrasonic extraction. The aqueous extract obtained by Soxhlet extraction showed the highest antioxidant activity. There was a positive linear correlation between total phenolics and flavonoids content with the antioxidant activity. The presented results suggest that aqueous extracts of dill fruit are a potential source of natural antioxidants as an alternative to synthetic additives. However, the determination of individual phenolic compounds responsible for the antioxidant activity, in vivo investigations of the antioxidant activity of these extracts, as well as their practical applications in food and pharmaceutical systems, should be the main goal of future investigations. 


\section{Acknowledgements}

This work was supported by the Ministry of Education, Science and Technological Development of the Republic of Serbia under the Project on Development of Technology number TR-34012.

\section{References}

[1] B. Tepe, E. Donmez, M. Unlu, F. Candan, D. Daferera, G. Vardar-Unlu, M. Polissiou, A. Sokmen, Antimicrobial and antioxidative activities of the essential oils and methanol extracts of Salvia cryptantha (Montbret et Aucher ex Benth.) and Salvia multicaulis (Vahl), Food Chemistry, 84(4) (2004) 519-525.

[2] P.J. Delaquis, K. Stanich, B. Girard, G. Mazza, Antimicrobial activity of individual and mixed fractions of dill, cilantro, coriander and eucalyptus essential oils, International Journal of Food Microbiology, 74 (2002) 101-109.

[3] D.M. Maestri, V. Nepote, A.L. Lamarque, J.A. Zygadlo, Natural products as antioxidants. In: Imperato F. (ed.), Phytochemistry: advances in research, Research Signopost, Kerala, India, 2006, 105-135.

[4] A.Y. Leung, S. Foster, Encyclopedia of common natural ingredients (used in food, drugs, and cosmetics), Second Edition, A John Wiley \& Sons, Inc., Hoboken, New Jersey, 2003, 210-212.

[5] Lj. Stanojević, B. Stanković, M. Cakić, V. Nikolić, D. Ilić, M. Perić, Uticaj tehnike ekstrakcije na prinos, kinetiku i sastav vodenih ekstrakata iz ploda mirođije (Anethi fructus), Advanced technologies, 2(2) (2013) 38-44 (In Serbian).

[6] E.I. Orhan, F.Z. Senol, N. Ozturk, S.A. Celik, A. Pulur, Y. Kan, Phytochemical contents and enzime inhibitory and antioxidant properties of Anethum graveolens L. (dill) samples cultivated under organic and conventional agricultural conditions, Food and Chemical Toxicology, 59 (2013) 96-103.

[7] J.A. Pino, A. Rosado, I. Goire, E. Roncal, Evaluation of flavor characteristic compounds in dill herb essential oil by sensory analysis and gas chromatography, Journal of Agricultural and Food Chemistry, 43 (1995) 1307-1309.

[8] G.J. Kaur, D.S. Arora, Bioactive potential of Anethum graveolens, Foeniculum vulgare and Trachyspermum ammi belonging to the familiy Umbelliferae - Current status, Journal of Medicinal Plants Research, 4 (2) (2010) 087-094.

[9] S. Koppula, D. K. Choi, Anethum Graveolens Linn (Umbelliferae), Extract Attenuates Stress-induced Urinary Biochemical Changes and Improves Cognition in Scopolamineinduced Amnesic Rats, Tropical Journal of Pharmaceutical Research, 10 (1) (2011) 47-54.

[10] H. Hosseinnzadeh, G. R. Karimi, M. Ameri, Effects of Anethum graveolens L. Seed extrats on experimental gastric irritation models in mice, BMC Pharmacology, 2 (21) (2002) 1471-2210.

[11] J. Tucakov, Lečenje biljem, RAD-Beograd, Beograd, 1997, 483-484.

[12] WHO monographs on selected medicinal plants. Vol. 3. (1. Plants, Medicinal. 2. Angiosperms. 3. Medicine, Traditional. I.) WHO Consultation on Selected Medicinal Plants (3rd: 2001: Ottawa, Ont.) II. World Health Organization, 2007, 33-38.
[13] A. Ortan, M. L. Popescu, A .L. Gaita, C. Dinu-Pirvu, Contributions to the Pharmacognostical Study on Anethum graveolens, Dill (Apiaceae), Romanian Biotehnological Letters, Romanian Society of Biological Sciences, 14 (2) (2009) 4342-4348.

[14] C. Sanchez-Moreno, Review: Methods Used to Evaluate the Free Radical Scavenging Activity in Foods and Biological Systems, Food Science and Tehnology International, 8 (3) (2002) 121-137.

[15] Lj.P. Stanojević, A.S. Zdravković, M.Z. Stanković, M.D. Cakić, V.D. Nikolić, D.P. Ilić, The antioxidant activity of aqueous-ethanolic extracts from nettle leaf (Urtica dioica L.), Advanced technologies, 2(1): (2013), 51-59 (In Serbian).

[16] I.F.F. Benzie, J.J. Strain, The ferric reducing ability of plasma (Frap) as a measure of "Antioxidant Power": The Frap Assay, Analytical Biochemistry, 239 (1) (1996) 70-76.

[17] Lj.P. Stanojević, J.S. Stanojević, D.J. Cvetković, M.D. Cakić, D.P. Ilić, (Antioxidant activity of ethanolic extract from cultivated strawberries leaves (Fragariae folium), Hemijska Industrija, 69(5) (2015) 567-576 (In Serbian).

[18] T.C.P. Dinis, V.M.C. Madeira, L.M. Almeida, Action of phenolic derivates (acetoaminophen, salicylate and 5 -aminosalycilate) as inhibitors of membrane lipid peroxidation and as peroxyl radical scavengers. Archives of Biochemistry and Biophysics 315 (1994) 161-169.

[19] M. Vinatoru, An overview of the ultrasonically assisted extraction of bioactive principles from herbs, Ultrasonics Sonochemistry, 8 (2001) 303-313.

[20] Lj.P. Stanojević, M.Z. Stanković, D.J. Cvetković, M.D. Cakić, D.P. Ilić, V.D. Nikolić, J.S. Stanojević, The effect of extraction techniques on yield,extraction kinetics, and antioxidant activity of aqueous-methanolic extracts from nettle (Urtica dioica L.) leaves, Separation Science and Technology, 51(11) (2016) 1817-1829.

[21] V.L. Christova-Bagdassarian, K.S. Bagdassarian, M.S Atanassova, Phenolic Compounds and Antioxidant Capacity in Bulgarian Plans (dry seeds), International Journal of Advanced Research, 1(9) (2013) 186-197.

[22] S.A. Budhiyanti, S. Raharjo, D.W. Marseno, I.Y.B. Lelana, Free radical scavenging, metal chelating and singlet oxygen quenching activity of fractionated brown seaweed Sargassum hystrix extract. Journal of Biological Sciences, 11 (2011) 288-298.

[23] I.T. Karabegović, S.S. Stojičević, D.T. Veličković, Z.B Todorović, N.Č. Nikolić, M.L. Lazić, The effect of different extraction techniques on the compositionand antioxidant activity of cherry laurel (Prunus laurocerasus) leaf and fruit extracts, Industrial Crops and Products 54 (2014) 142-148. 
Izvod

\section{ANTIOKSIDATIVNA AKTIVNOST VODENIH EKSTRAKATA PLODA MIROĐIJE (Anethi fructus) DOBIJENIH RAZLIČITIM TEHNIKAMA EKSTRAKCIJE}

Ljiljana P. Stanojević ${ }^{1}$, Mihajlo Z. Stanković ${ }^{1}$, Amer Juma ${ }^{2}$

${ }^{1}$ Tehnološki fakultet, Bulevar Oslobođenja 124, 16000 Leskovac, Univerzitet u Nišu, Srbija

${ }^{2}$ Al. Rafideen doo, Leskovac, Serbia

$U$ radu je prikazana antioksidativna aktivnost vodenih ekstrakata ploda mirođije (Anethum graveolens L.) primenom DPPH, FRAP i FIC testa. Vodeni ekstrakti su dobijeni iz ploda mirođije primenom različitih tehnika ekstrakcije (maceracija, refluks ekstrakcija, Soxlet, Tillepape i ultrazvučna ekstrakcija). Najbolju antioksidativnu aktivnost pokazao je ekstrakt dobijen Soxhlet ekstrakcijom, nezavisno od primenjene antioksidativne metode. Utvrđena je pozitivna linearna korelacija između antioksidativne aktivnosti i sadržaja ukupnih fenola i flavonoida. Prikazani rezultati ukazuju da su bioaktivne komponente, fenoli i flavonoidi najverovatnije odgovorni za antioksidativnu aktivnost ekstrakata. Rezultati takođe pokazuju da vodeni ekstrakti ploda mirođije predstavljaju potencijalni izvor prirodnih antioksidanasa, kao moguća alternativa sintetskim antioksidansima.
(ORIGINALNI NAUČNI RAD)

UDK 582.794.1:66.061

Ključne reči: Anethum graveolens L., Plod mirođije, Tehnike ekstrakcije, Antioksidativna aktivnost, Ukupni fenoli $\mathrm{i}$ flavonoidi 